\title{
Correlative Analysis Between the Freezing Point and the Microbial Content of Milk Obtained From Indigenous Cows Breed in a Sub-Carpathian Mountain Area
}

\author{
Ramona BLIDAR, Rodica SOMEȘAN, Sergiu MUNTEAN, Alina NĂS̆̆LEAN, Laurenț OGNEAN* \\ Department of Physiology, University of Agricultural Science and Veterinary Medicine Mănăștur street, \\ no. 3-5, 400037, Cluj-Napoca, România \\ *corresponding author: lognean@yahoo.com
}

Bulletin UASVM Veterinary Medicine 73(2) / 2016,

Print ISSN 1843-5270; Electronic ISSN 1843-5378

DOI:10.15835/buasvmcn-vm: 12256

\begin{abstract}
Through research in this paper we propose to analyze new criteria for evaluation of freshness and health of milk obtained in conditions of mountain areas, based on the freezing point - TNG correlation.

During a time of 2 years there were investigated physicochemical and microbiological milk samples commodities from the mountain area Valea Gurghiului. Milk samples were collected from cows of indigenous breed belonging to traditional households $(n=650)$, to micro farms $(n=11)$ and commercial farms $(n=2)$. From each source were analyzed 10 samples of milk each month, having a total of 240 sample/lot or 720 per entire amount of processed milk.

The evolution of the freezing point was characterized by insignificant statistically differences and very close mean values among 3 samples and by significant statistically differences between winter seasons with the highest values and autumn, with the lowest levels. At the level of the lot, TNG has reached higher levels $(71.210 \mathrm{CFU} / \mathrm{mL})$ in the case of milk from individual farms. The evolution of the seasonal influences revealed minimal levels ( 64.300 $\mathrm{CFU} / \mathrm{mL})$ in summer and the maximum levels in the autumn $(76.720 \mathrm{CFU} / \mathrm{mL})$, with statistically significant differences. We believe that seasonal patterns, with statistically significant differences, marked by significant decreases of the freezing point during autumn, associated with minimum values of TNG in summer and maximal in autumn, support the implementation of the freezing point - TNG correlation in the evaluation of the freshness and health of milk obtained in mountainous areas.
\end{abstract}

Keywords: freshness, mountain area, raw milk, TNG.

\section{INTRODUCTION}

In obtaining traditional milk products, a distinct role employ the mountainous geo-climatic conditions, which can significantly influence the wealth and the health of the animals and mostly the compositional and microbiological characteristics of milk (Ognean et al, 2012; Someşan, 2013), more precisely, the nature and the abundance of germs, which will later influence the sensorial characteristics of cheese acquired in this kind of conditions (Lafarge, 2004; Ognean, 2008). The microbiocenosis of milk is influenced by different factors, the most important oscillations being related with the conditions of milking and maintenance, the health of mammary gland, the level of lactation, the nutritional management, the season, the age and race of the animal. All these influences are reflected in the quality of milk acquired in mountainous conditions areas; which ensure higher levels of lactating cow's wealth and health and implicitly of the quality of feed. In any processing system the compositional and microbiological characteristics of milk and of dairy products should be carefully monitored and 
managed through biochemical and technological processes, in order to raise the nutritional value and food safety standards at the biggest possible add (Olechnowicz et al., 2012; Ognean, 2008). The food safety in the field of dairy products currently establishes a priority issue of global concern, being a major objective for ensuring public health (Thomas, 2013).

\section{MATERIALS AND METHODS}

This study focuses on the analysis of new criteria for assessing freshness and health of milk, based on correlation of freezing point with the total number of germs (TNG).These parameters are taken from the overall analysis of the physico-chemical and microbiological (TNG and NSC) indices of the milk freight, processed in a private processing unit. Freight milk samples investigate was prepared under the mountain area Valea Gurghiului, coming from the cows from predominant indigene races, grown in traditional households and commercial farms. Among them, the major share comes to small producers, with an average of 3 lactating cows, which ensure the main source of milk in the area.

They produce the milk under conditions of traditional household, predominantly with manual milking, the percentage of those who use mechanical milking equipment being insignificant. Lately the share of small size farms has grown in the area. Actually those have an average effective of 79 lactating cows and have good hygienic conditions, being equipped with automatic milking installations and their own cooling tanks. A small portion of milk is produced in 2 large commercial farms, whose average effective reach to 200 cattle. Those have excellent conditions of zoo hygiene and hygiene of milking, being equipped with automatic milking halls, which also present type Aquarius equipment for automatic signalization of mastitis.

The predominant race in the area is "Bălțată Românească" and its half-breed, from which through long selections were made lines of cows with high capacity to adapt to local conditions and resistance to disease. Relating to the feeding treatment of lactating cows I mention that it relies on natural grazing during the summer, respectively based on hay, obtained in natural conditions of the area during the calves completing with concentrate based on corn.
The research began by identifying milk supplier's freight, which can be framed in standards of product, established by legislation requirements and by the processing unit and their grouping on milk supply source, result the samples. A - milk produced in small households $(n=65) B-$ milk supplied by micro farms (small size farms) $(\mathrm{n}=11)$ and $\mathrm{C}-$ milk which come from large farms $(n=2)$.

Milk from small producers was received in 6 collection points, which are organized and managed by the processing unit. In case of both micro farms and large farms the usage of their own cooling tanks allowed receiving the milk directly from the farm. The average quantity supplied daily by the components of the three sources has been calculated at $24.6 \mathrm{~L} /$ individual producer, $909 \mathrm{~L} /$ micro and $300 \mathrm{~L} /$ large farm. The summarization of those source provided a total of $32000 \mathrm{~L}$ of milk daily processed, of each 16000 were from households, 10000 L from micro farms and only $6000 \mathrm{~L}$ from large farms.

During its investigations (20 months) from each sample was harvested 16 milk assays and were subjected to laboratory analysis. The final result was a total of 960 assays; 320for each sample.

The physico-chemical testing of collected assays was performed with a semi-automatic analyzer (Milkana KAM 98-2A), which allowed the determination of basic indices, set out in motional standards: fat, free dry matter (SUN), protein, freezing point, density and acidity. We note also that the results acquired with device Ekomilk were validated through usual methods in case of fat (butirometry), dry substance (dry in oven), density (termolactodensimetry) and acidity (titrimetry/ $\mathrm{pH}$ ).

Hygienic and sanitary quality of milk was evaluated by cytological and microbiological analysis of assay taken from the three samples, during 24 months. Thus, each month were analyzed 10 assays of milk per sample, resulting at the end 240 assays of milk per sample for a total of 720 assays investigated. Sampling procedure of assays complied with current standards, these being collected in sterile containers of 60 $\mathrm{mL}$ (no added preservative), ensuring optimal temperature conditions $\left(4^{\circ} \mathrm{C}\right)$, not only during the transport but also after their receipt in the laboratory. Cytological and microbiological assays 
were performed within the first 2-4 hours of collection, in plant laboratory of the company studied, using automatic systems, Soleris type for TNG (with automatic colorimetric detection of milk nutrient agar culture) and Ekoskope for NCS.

The obtained data were statistically analyzed using MedCalc, designed to statistics in biomedical research, and Graph Pad Prisma. The analysis of descriptive data and the distribution of variables were performed using summary statistics and frequency analysis while plotting the recorded data was based on the use of diagrams of "box plot". In this diagram, each "box" represents the values of $25-75 \%$ quartiles series of values, and the line of each "box" represents the median of the group. Meanwhile, lines that extend each "box" (vertical or horizontal), indicates fourth quartile. The Anova, Bonferroni's Multiple Comparison and Chi-square were also used, and allowed the comparison of difference between the average values of three samples, $\mathrm{p}<0.05$ indicating statistical differences between groups. Final interpretation focused mainly in developments of freezing point and of TNG-S, and the statistical analysis the correlation between these indices and seasonal influence.

\section{RESULTS AND DISCUSSIONS}

Comparative analysis on samples and on seasons of the results achieved in these physicchemical tests revealed significant oscillations of parameters investigated, especially regarding the origin of commodity milk (Tab.1). The evolution of freezing point $\left({ }^{\circ} \mathrm{C}\right)$ indicates statistically insignificant differences $(p=0.071)$ between samples, with very close average values, between $-0.566^{\circ} \mathrm{C}$ and $-0.565^{\circ} \mathrm{C}$ for those three samples (Tab.1).

The comparative seasonal analysis average values of milk's freezing point originated from those three sources revealed the achieving of the highest values $\left(-0.560^{\circ} \mathrm{C}\right)$ during winter and to the lowest ones $\left(0.571^{\circ} \mathrm{C}\right)$ during autumn with statistically significant differences between the two seasons ( $p=0.0001)$ (Fig.1). During the comparative assessment on the source and seasons, the evolution of TNG values for commodity milk revealed significant oscillations, but come under standards which are admitted for drinking milk (Tab.2). In this regard were recorded the following average levels inserted in case of those three samples: $71.210 \mathrm{CFU} / \mathrm{ml}$ for

Tab.1.The distribution of average values milk of freezing point $\left({ }^{\circ} \mathrm{C}\right)$ on samples

\begin{tabular}{cccc}
\hline & Households & Microfarms & Large farms \\
\hline Number of samples & 320 & 320 & 320 \\
\hline Minimum & -55.00 & -50.67 & -50.10 \\
\hline Median & -56.40 & -56.40 & -56.40 \\
\hline Maximum & -61.90 & -60.70 & -65.40 \\
\hline Mean & $-\mathbf{5 6 . 6 6}$ & $\mathbf{- 5 6 . 6 5}$ & $\mathbf{- 5 6 . 5 9}$ \\
\hline SD & $\mathbf{1 . 1 3 1}$ & $\mathbf{1 . 0 8 1}$ & $\mathbf{1 . 2 0 8}$ \\
\hline
\end{tabular}

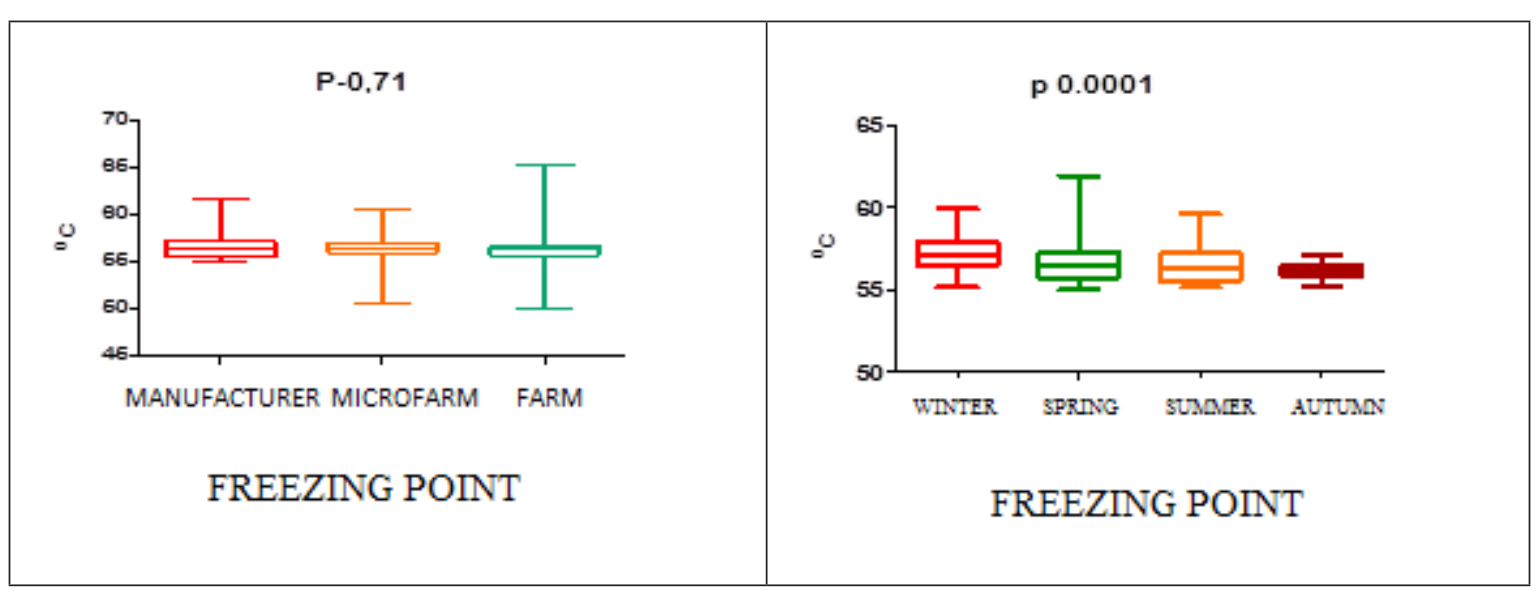

Fig. 1. Evolution of average values of the milk freezing point $\left({ }^{\circ} \mathrm{C}\right)$ on samples and seasons 
the milk from households; $56.950 \mathrm{CFU} / \mathrm{ml} \mathrm{CFU/}$ $\mathrm{ml}$ for those coming from micro farms and 50.570 $\mathrm{CFU} / \mathrm{ml}$ for those coming from large farms.

As can be seen in Figure 2, the values of this parameter showed oscillations grouped in the middle area of accepted standards, but with some statistically significant differences between samples. Regarding the seasonal comparative evolution of TNG in milk assays, which comes from those three sources, we found minimal attainment values $(64.300 \mathrm{CFU} / \mathrm{ml})$ in summer and maximum in autumn $(76.720 \mathrm{CFU} / \mathrm{ml})$ with statistically significant differences between these seasons (Fig. 2).

The setting of limits for the freezing point of commodity milk is very important, because this parameter gives us clues upon one possible falsification of commodity milk by adding water, but also upon the health of the breast (Ognean, 2012). According to rules, for the studied product the boundaries of the freezing point are between -0.53 and $-0.57^{\circ} \mathrm{C}$, having an average of $-0.555^{\circ} \mathrm{C}$. The average values for investigated samples showed great development of the freezing print, as a key indicator of the milk freshness $\left(-0.566^{\circ} \mathrm{C}\right.$ for samples $\mathrm{A}$ and $\mathrm{B}$ and $-0.565^{\circ} \mathrm{C}$ for sample $\mathrm{C}$ ) with statistical significant differences $(p=0.071)$.
The same relevance also had the comparative analysis on the seasons of this parameter, the obtained data indicating higher values $\left(-0.560^{\circ} \mathrm{C}\right)$ in winter and lower $\left(0.571^{\circ} \mathrm{C}\right)$ in autumn, between the two season being statistically significant differences $(p=0.001)$. Taken as a whole, the results of physico-chemical testing of the studied milk samples showed their inclusion in national and European standards for raw milk. The results of these statistical analysis confirm once again that the correlation values of compositional index with the microbiological ones have major relevance in assessing the quality and safety of milk commodity and hence the economic efficiency of producers and processors (Dobranié,2008; Ognean, 2008; Năsalean, 2015).

Regarding microbiological component of raw milk, the data showed significant oscillations of TNG, being influenced by both variable sample and variable season. In this regard we only mention that the highest levels of TNG $(71.210 \mathrm{CFU} / \mathrm{ml})$ were found in the sample of milk from small producers with minimum values (64.300 CFU/ $\mathrm{mL}$ ) in summer and the maximum in the autumn $(76.720 \mathrm{CFU} / \mathrm{ml})$ and statistically significant differences $(p=0.0001)$ between these seasons.

Tab. 2. The distribution of average values milk TNG (CFU/ml) on samples

\begin{tabular}{cccc}
\hline & Households & Microfarms & Large farms \\
\hline Number of samples & 227 & 233 & 237 \\
\hline Minimum & 30.00 & 16.00 & 10.00 \\
\hline Median & 73.00 & 59.00 & 51.00 \\
\hline Maximum & 99.00 & 87.00 & 99.00 \\
\hline Mean & $\mathbf{7 1 . 2 1}$ & $\mathbf{5 6 . 9 5}$ & $\mathbf{5 0 . 5 7}$ \\
\hline SD & $\mathbf{1 2 . 7 9}$ & $\mathbf{1 4 . 0 8}$ & $\mathbf{1 7 . 2 7}$
\end{tabular}

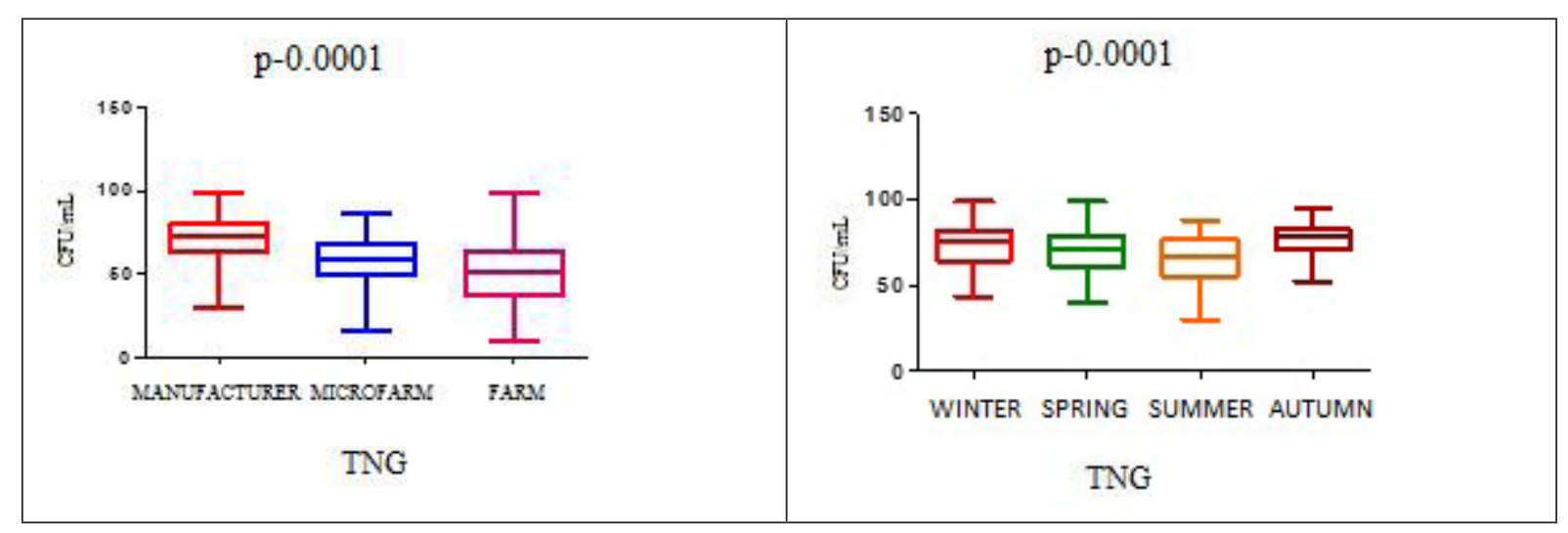

Fig. 2. Evolution of average values of milk TNG on samples and seasons 
Compared with developments inserted by us it should be noted that other studies show higher levels of TNG for milk from farms which grow up animals in traditional systems. Moreover, some have demonstrated that milk which comes from conventional conditions may contain fewer germs than the one processed in ecological conditions, the noted differences not being biologically relevant (Vicini, 2008). It should also be noted that from traditional households, the milk should be collected twice a day, giving up keeping it for the next day and hence giving up the microbiological risk it would be a subject to (Griffiths, 1990; Lafarge, 2004; Verdier-Metz, 2012).

\section{CONCLUSIONS}

The overall analysis of freezing point values revealed statistically insignificant differences between the samples $(p=0.071)$ of raw milk investigated, seasonal influences revealing more significant decreases of this parameter in autumn $\left(-0.571^{\circ} \mathrm{C}\right)$, with statistically significant differences compared to other seasons $(\mathrm{p}=0.0001)$.

Microbiological tests showed higher levels of TNG (71.210 CFU/mL) for milk from small farm producers, with minimal values in summer $(64.300 \mathrm{CFU} / \mathrm{mL})$ and the maximum in autumn $(76.720 \mathrm{CFU} / \mathrm{mL})$ and statistically significant differences between these seasons $(p=0.0001)$.

The results obtained in the investigation of samples of raw milk from traditional households, micro and large farms revealed significant oscillation of compositional and hygienic parameters, showing the differences in hygiene, maintenance and feeding assured for cows from the three sources of supply.

I attributed particular relevance to the correlative evolution of increasing levels TNG and decreasing freezing point values, results that support the implementation of freezing - point correlation TNG in freshness and health evaluation of milk from mountainous areas.

\section{REFERENCES}

1. Dobranié V, Njari B, Samardzija M, Mioković B, Resanović $R$ (2008). The influence of the season on the chemical composition and the somatic cell count of bulk tank cow's milk. Vet Arhiv 9:235-242.

2. Griffiths MW, Phillips JD (1990). Incidence, source and some properties of psychrotrophic Bacillus found in raw and pasteurized milk. Journal of the Society for Dairy Technology 43:62-66.

3. Lafarge V, Ogier JC, Girard V, Maladen V, Leveau JY, Gruss A, Delacroix-Buchet A (2004). Raw Cow Milk Bacterial Population Shifts Attributable to Refrigeration. Appl Environ Microbiol 70(9):5644-5650.

4. Năsalean A, Stefănuţ C, Pall E, Someşan R, Ognean L (2015). Comparative Analysis of Fat and Protein Content in Milk from Alpine and Carpathian Goats. Bulletin UASVM Veterinary Medicine 72(2):250-253.

5. Ognean L, Cernea C, Cernea M (2008). Evolution of cow mammary health and the hygienic and sanitary parameters of produced and processed milk on the closed chain productive flow of the Sanlacta Company. USAMV Iaşi Lucr.St. Seria MV 51(10):103-108.

6. Ognean L, Cernea C, Fiţ N, Moldovan M, Someşan R, Dragomir D (2012). The evaluation of the milk health and conformity level on a processing company chain with close and open circuit. Universitatea de Ştiinţe Agricole şi Medicină Veterinară Iaşi, Lucrări Ştiinţifice seria Medicină Veterinar, 55:1-7.

7. Olechnowicz J, Jaśkowski JM (2012). Somatic cells count in cow's bulk tank milk. J Vet Med Sci 74(6):681-6.

8. Someşan R, Popa D, Blidar R, Ognean L (2015). Influence of Climatic Factors in a Subcarpathian Mountain Range on Fat and Protein Content of Raw Milk from Indigenous Breed. Bulletin UASVM Veterinary Medicine 72(1):128133.

9. Verdier-Metz I, Gagne G, Bornes S, Monsallier F, Veisseire P, Delbès-Paus C, Montel MC (2012). Cow Teat Skin, Potential Source of Diverse Microbial Populations for Cheese Production. Appl Environ Microbiol 78(2):326333.

10. Vicini J, Etherton T, Kris-Etherton P, Ballam J, Denham S, Staub R, Goldstein D, Cady R, Mcgrath M, Lucy M (2008). Survey of retail milk composition as affected by label claims egarding farm-management practices. J Am Diet Assoc 108(7):1198-1203. 